\title{
二条城二の丸御殿の大広間等諸御殿の復原研究 \\ 一建築と障壁画の総合的検討一 \\ A STUDY ON THE ORIGINAL PLAN AND THE PANEL PAINTINGS OF NINOMARU PALACE OF NIJO CASTLE
}

\author{
西 和夫*, 小沢朝 江** \\ Kazuo NISHI and Asae OZAWA
}

\begin{abstract}
This is a study on the original plan and the panel paintings of the Shirosyoin of Ninomaru Palace of Nijo Castle. The results are as follows.

1. The Keicho plan of the Ohiroma can be reconstructed. The alcove and the shelves were originally on the north of the jodannoma and tukesyoin. was on northwest of that room.

2. The length of papers of wall paintings can be classified in to three groups of the Shirosyoin, Kurosyoin, and the others.
\end{abstract}

\author{
Keywords : Ninomaru palace of Nijo castle, Ohiroma Syoin style, original plan, \\ panel paintings, length of papers \\ 二条城二の丸御殿、大広間、書院造、復原平面、障壁画、料紙寸法
}

はじめに

二条城二の丸御殿は、すでに知られている通り から8年にかけて(以下これを慶長度造営と呼ぶ) 徳川家康によって 造営が行われ、寛永 3 年(1626)の後水尾天皇の行幸に備えて同元年 から3年にかけて(これを寛永度造営と呼ぶ) 徳川家光によって、慶 長度御殿の柱などを生かして新築に近い改築を行ったものとされて いる。

二の丸御殿のうち白書院については、先に、慶長度御殿の復原平 面を提示し、また、現存する障壁画が寛永度のものであることなど を明らかにしだ2。

本稿は、白書院以外の御殿について、大広間を中心に慶長度御殿 の復原検討を行い、また二の丸御殿全体の障壁画について料紙寸法 の検討を行って、判明した諸点を報告するものである ${ }^{3)}$ 。

\section{1 .大広間の復原検討}

\section{1- 1 部材痕跡等による検討}

大広間一の間（上段の間）と二の間 (下段の間) の柱には図1の $\mathrm{J} \cdot \mathrm{k} \cdot \mathrm{L} \cdot \mathrm{M}$ 柱に埋木や当木があり、これによって現在 2 室構 成のここがもと 3 室構成であったことが判明し、また『義演准后日 記』や『言経卿記』によって慶長度は上段・中段 · 下段の 3 室構成
だったことが裏付けられることをすでに報告した ${ }^{4)}$ 。以下にその後判 明した諸点を示そう5)。

一の間（上段の間）のトコ・棚後方の 3 本の柱 $\mathrm{A} \cdot \mathrm{B} \cdot \mathrm{C}$ には天

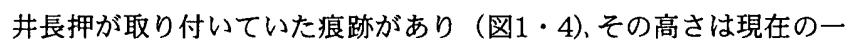
の間の天井長押と同じである。また、トコ・棚前面の柱 $\mathrm{D} \cdot \mathrm{E} \cdot \mathrm{F}$

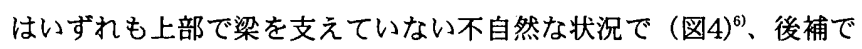
あることが明らかである。慶長度にはトコと棚は現在の位置にな く、現在のトコ・棚のところまで一の間の天井が入り込んでいた。 現在のトコ・棚は寛永度に作られたものとなる。

図 1 のGの位置、ここは現在のトコの北西隅柱Aから慶長度の上 段・中段境の柱 $\mathrm{J}$ までの距離を二等分する位置であるが、この位直 の梁に柱のほぞ穴があり（図5)、しかもこの位置の床下に現在使われ ていない（柱も束も支えていない）礎石があって、慶長度に柱が立 っていたことを示している。ここに柱が立てば現在の付書院は存在 しえないから、付書院は寛永度に作られたことになる。

柱 Cの南面と柱 $\mathrm{K}$ の北面には、高さ 1 尺 7 寸ほどの小壁が天井か ら下がっていたことを示す痕跡がある。一の間と帳台の間はユカの 高さが同じで、しかも両室は大引が通っている。また、柱 CとKの 中央の位置( I )に釣束の痕跡が梁側面にある7”。すなわち、一の間と 帳台の間は天井から下がる小壁だけで区切られ、ユカが通った状況
* 神奈川大学工学部建築学科 教授・工博

** 湘北短期大学生活科学科 専任講師・工修
Prof., Dept. of Architecture, Faculty of Engineering, Kanagawa University, Dr. Eng. Lecturer, Dept. of Living Science, Shohoku College, M. Eng. 
にあった。帳台構は現在の位置になかったことになる。

一の間と二の間は現在折上格天井で、二の間の天井長押の高さは 一の間より 5 寸低い。しかし、二の間の柱には現在の一の間と同じ 高さに天井長押の痕跡があって、慶長度には上・中・下段とも天井 長押の高さは同じだったことになる。ただし、現在の一の間の南寄 り（もと中段部分）の天井は、梁を欠いて無理に折上格天井を入れ ており、当初は上段の間のみ折上天井で、中・下段は平天井だった と考えられる。

現在の二の間と三の間の境は澳と彫刻欗間で仕切られているが、 柱M・Pにはかつて二の間から三の間へ天井長押がそのまま延びて いたことを示す痕跡がある。柱Mから柱 $\mathrm{P}$ の間には貫が 1 本も入ら ず、また鴨居と内法長押は東西方向の長押を切って入れている。以 上のことから、この間仕切は寛永度のもので、慶長度には下段の間 と現在の三の間が連続した一室であったと考えられる。

\section{1-2 座敨飾等の恰的}

以上のように、現在のトコ・棚・付書院・帳台構はいずれも慶長 度には現位置になかったことが判明したが、慶長度に座敨飾がひと つもなかったとは考え難く、どこにあったかが次の問題となる8 。ま ずトコは、柱 $\mathrm{A} の$ 東面および柱 $\mathrm{B}$ の西面に内法長押や鴨居が取り付 いていた痕跡がなく9、建具にも貼付壁にもなりえないから、ここが トコであったと考えられる。落し掛の存在を明示する痕跡はない が、天井迴緑に接するほど高い位置に落し掛があったとすれば10)、 室外に北に張り出す形式のトコがここにあったと考えて矛盾しな い。すでに指摘したように"1)、慶長度に家康が諸大名と対面したと き、ここが家康が坐った背後になり、この位置にトコがあった蓋然 性は高い。棚は、柱 B とCが慶長度の位置を保っていると考えられ るので、柱 $\mathrm{B}$ とC間にあったと考えざるをえない。トコ・棚がこ のように復原された結果、付書院は、柱 $\mathrm{A}$ と復原された柱 $\mathrm{G}$ との間 にあった可能性が高い。しかし、帳台構については、その位置は不 明である。

ここで考えておかねばならないのは、帳台の間・物置・四の間の あたりは寛永度の改变が甚だしいのではないかという点である。

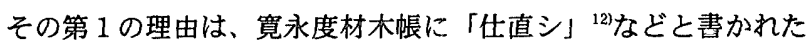
改造を明示する材は、慶長度の中段の間のうち21.3睤分（東西 4 間、南北 4 間 $\times 2 / 3$ ) 寛永度の一の間（上段の間）に改造するた めのものと考えたとき、面讂が一致し、仕直シ」されたのがこのあ たりだけだった可能性が高いことである。すなわち、寛永度の材木 帳に「仕直シ」などとある材は 5 種類しかなく、このうち桧割木・ 1 尺角・長 3 間半・ 8 本、桧・ 6 寸角・長 2 間・ 15 本、杉四々料・ 1 尺 5 寸 $\times 5$ 寸・長 7 尺・46枚、以上の 3 種類は寸法等からそれぞ れ大引、根太、ユ力板の材と判断され ${ }^{13}$ 、ここ 3 種頶の枋で構成さ れる床面樻は、慶長度の中段の間の21.3盢の部分に合致する ${ }^{14) 。 ~}$

一方、 5 種類の枋と同寸法の枋は、同じ材木帳で「仕直シ」と書 かれていない大広間の材の中にもあり、その本数は根太と考えられ る材が464本、ユ力板と考えられる枋が524枚で、ユ力面䅡にすると 約350疊分に当たる ${ }^{15)}$ 。この面穦は、現在の大広間のうち、慶長度の 上段・中段部分を除いた面䅡 (入側を含む)に該当し、この部分の材 は寛永度に新たに購入している。また小屋材は、6 間長さの大梁 ${ }^{16)}$ をはじめ、野垂木と考えられる材 ${ }^{17} か ゙ 503$ 本あるなど、大広間全体の 小屋を構成するに十分な量が購入されており、小屋は䙾永度に全面 的に作り直されたと考えざるをえない。さらに、四の間天井迴緑に に二云、五味金右衛門、御ひろま東ノ口間]，一の間天井支輪に[御 ひろ間上たん西かわ、いノ六、五味金右衛門」など、寛永度の大広 間の造営奉行である五哧金右衛門 ${ }^{18}$ の名があり（図6）、白書院とは 異なり、大広間は寛永度に天井を新たに作っていることが明らかで ある。このように、慶長度の枋を生かして「仕直シ」すなわち改造 を行ったのは慶長度の上段・中段まわりであって、それ以外は「仕 直シ」ではなく全面的な改変であったと考えるのが妥当である。

第 2 の理由は、大広間の柱の中で太い柱は図 1 に示す 7 本で、い ずれも構造上の重要な位置に配されており、構造上の配虑が十分に なされていることを明示するにもかかわらず、帳台の間・物置の東 端の柱N以外、太い柱は一の間·二の間まわりにしかない点である。 また、柱Nの南北柱列は、この位置に大梁を載せているにもかかわ らず、柱Nを南にのばした位置には柱がなく、大梁南端を柱が受け ていない ${ }^{99}$ 。構造上はここに柱があるべきだが、このいわば構造上

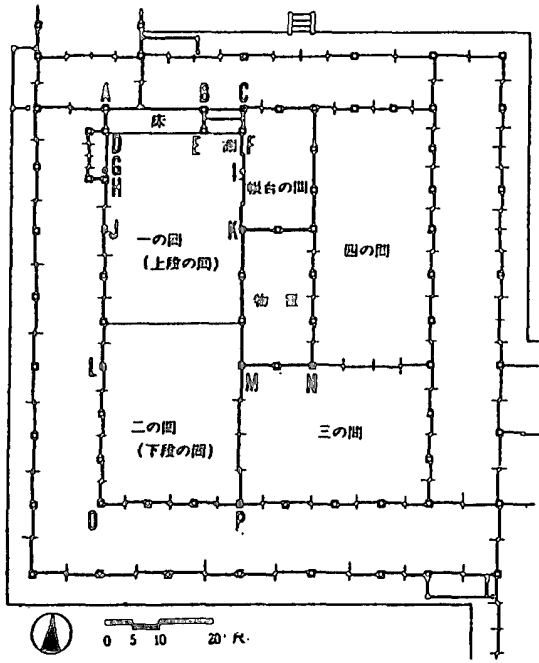

図1大広間 現状平面図

[四は太い柱、○は痕跡により復原 される柱または束]

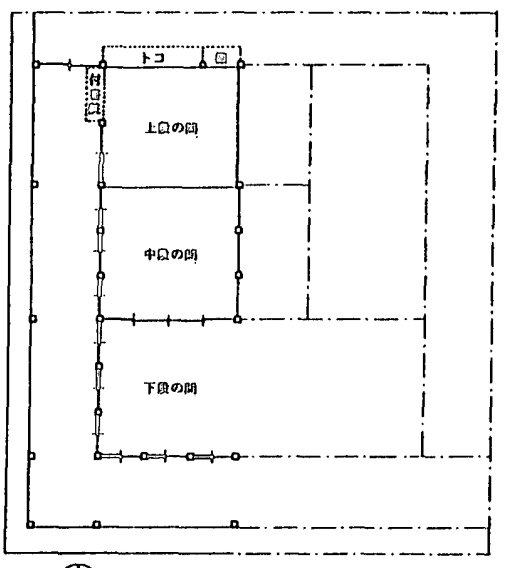

(1)

図2 慶長度大広間 復原平面図

[寛永度造営で全面的に改造された と考えられる部分は、一点鎖線で 現在の間仕切を示した]

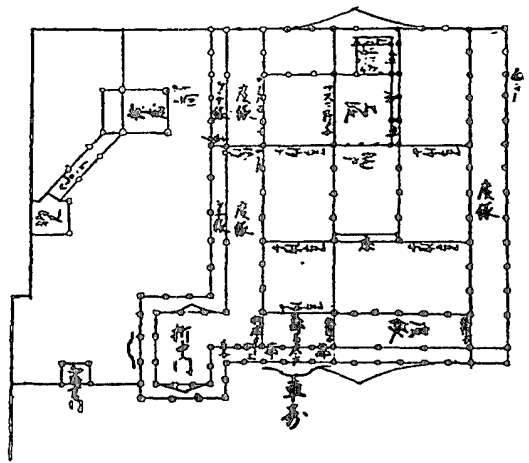

図 3 『匠明』殿屋集「当代広間之図」 
の配慮の乱れは、大広間の東半分を大規模に改造したために生じた のではないかと考えられる。

第 3 の理由は、三の間や四の間の柱は、太い柱Nの南面を除き痕 跡が全くないことである。一の間や二の間に多くの痕跡があるのに 比べてやや奇異な感じを受ける。これも、ここが全面的に改変され たとすれば矛盾なく理解できる。

以上のように、帳台の間・物置・四の間等は寛永度に大きな改変 を受けたと考えられ、慶長度の平面をそのまま踏襲している可能性 は低い。慶長度の帳台構の位置が不明なのは、そのためではないか と考えられる。

\section{1-3 慶長度平面の復原}

以上の検討をもとに、大広間の慶長度平面を復原すると図 2 のよ うになる。先に述べたように、トコ・棚・付書院については可能性 の指摘はできても不明な点が残っているため、復原平面では点線で 表示した。

大広間は慶長度には上・中・下段の 3 室構成であったが、現在室 内には慶長度のユ力の高さを示す痕跡は見えていない200。ユカ高に 3 段の段差を持つ部屋を 2 段に改造し、室内に痕跡を見せないため には、慶長度の上段が現在の一の間のユ力高、慶長度の下段が現在 の二の間の高さで、それを現状のように改変するしか方法がない。 先に述べたように、寛永度の材木帳のうち「仕直シ」と書かれた根 太等のユ力材の量は、慶長度の中段の間のうち寛永度に一の間（上 段の間）に改造したと考えられる部分のユ力面積に合致し、この検 討を裏付ける。

慶長度の平面のうち判明した部分を見て気付くのは、『匠明』殿 屋集に示された「当代広間ノ図了(図 3$)^{21}$ 之の類似性である。ただ し、「当代広間ノ図」には上々段・折中門・車寄があるが、大広間の 復原平面にはない。また、3 室が一列に並ぶ部分はユ力高の記入が なく、これらと鍵手に慗がる部屋に「上段」とあり、ここに「床」 「棚」が付き、この「段」と接続する部屋との境は「フスマ障子」 となっている。このように種々の相違はあるが、3 室連続した部屋 があること、その第 3 室とそれに接続する部屋との境は建具がない こと ${ }^{22)} と ゙$ 類似する点も多く、類似平面のひとつとして参考になろ う。

\section{2 .黑書院・式台・遗侍の復原検討}

\section{2-1 黒書院}

黒書院は、室内・床下 - 小屋裹に復原資料となるような痕跡がな く、寛永度造営で平面の大規模な改変が行われた可能性は低い。し かし一方、寛永造営時の大工工数が同時期に造営された行幸御殿等 と比べて少ない ${ }^{23)}$ た、全くの新築とは考えられず、また四の間の 天井格緑に「うしノ寛永二年」の墨書がある（図 7）から、寛永度 に工事が行われていることも明らかである。ただし、寛永度造営の 材木帳に書き出された黒書院の材は、大広間の同寸法のものと比べ 本数が少なく24)、材木帳がすべて残存してはいないので断定はでき ないものの、大広間に比べて黒書院の改造が小さかったことを筧わ せる。すでに報告したように25)、白書院の平面は慶長度には現状と 大きく異なっているが、慶長度の黒書院から白書院への廊下は、寛 永度の廊下 ${ }^{26)}$ と同様東側に設けられ、黒書院牡丹の間から白書院東 指出へ出るようになっていたと考えられる。

黒書院の現状平面は、元和 2 年(1616)の名古屋城本丸広間および 御殿の 2 棟の平面 ${ }^{27} に よ よ く$ 似ている。黒書院が幅 2 間の帳台の間を 設け、その東側を四の間としているのに対し、名古屋城本丸広間と 御殿は帳台構の裏を広い帳台の間としており、この点が相違するも のの、上段の間より下段の間の幅が広いことなど、共通点が多い。 黒書院の平面が慶長度からのものであった蓋然性は高い。

\section{2-2 式台・遠侍}

遠侍は、芙蓉の間北西隅柱北面の内法長押とほぼ同じ高さにある 埋木以外、室内に見えている痕跡はないが、帳台の間が上段の間側 からしか出入りできないなど、平面に不自然な点が見られる ${ }^{28)}$ 。遠 侍の小屋組のうち、入側縁の内側柱列に載る敷杵には「東かわ南ノ はな」など位置を示す彫込みがあるが、この敷析と同様の材は物置 ・芙蓉の間の北側・南側および芙蓉の間東側の柱筋上にもあり、そ れぞれ「北中とをり」「南ノ中とをり」「北ノ中とをり」との彫込 みがあって、慶長度にここが部屋境であったことを示している。ま た、物置部分に架かる梁はいずれも転用材で、この部分が寛永度の 改造であることを示唆する。敷枌の位置とも考えあわせると、かつ ては物置部分が中庭であった可能性があるが、これ以上の資料を欠 き、断定はできない。

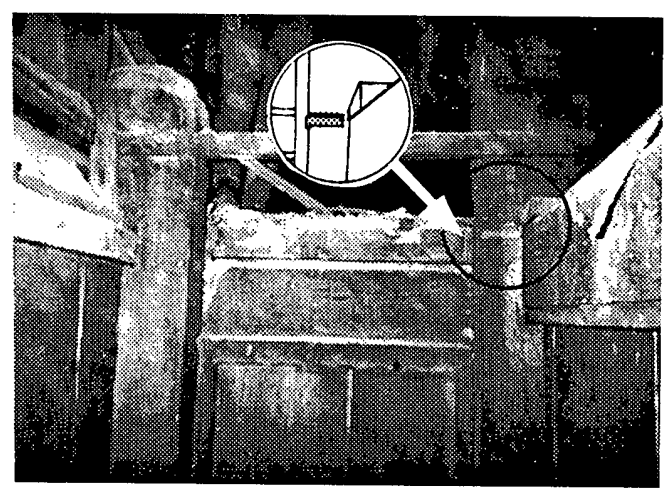

図 4 柱 $\mathrm{B} \cdot \mathrm{E}$ の痕跡

[右がB、左がE。上の図は○部分の説明図。アミかけ 部分が内法艮押の痕跡。Eの顶部は染を支えていない]

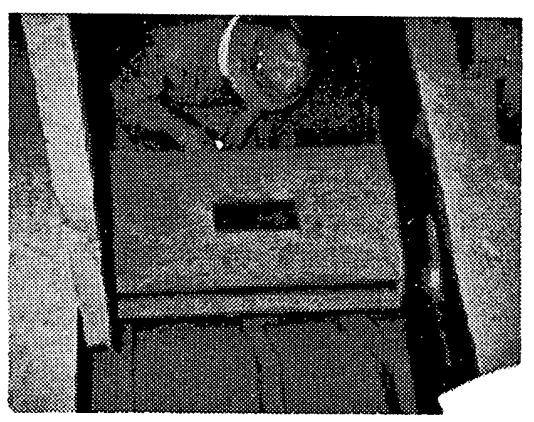

図 5 旧柱位置 G ほぞ穴

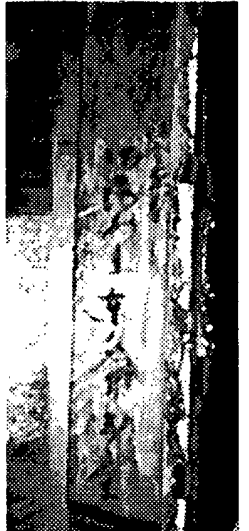

図6 大広間上段の間 天井格縁墨書

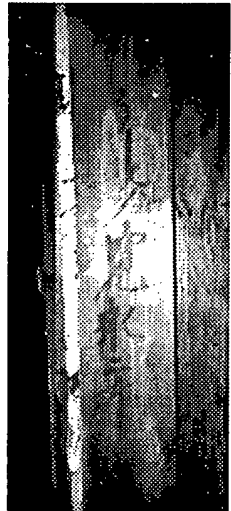

図 7 黒書院四の間 天井格縁墨書 
式台は、寛永度の材木帳に「仕直」「作直シ」と書かれた材が含 まれていて ${ }^{29}$ 、慶長度の御殿を改造して用いたことは明らかである。 しかし、大広間と同様に、「仕直」と書かれた材と比べ、同じ寸法 で「仕值」と書かれていない材の方がはるかに量が多く30，大規模 に改造されたことを示している。式台が大広間と遠侍の間に後から

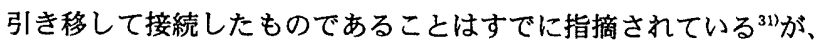
小屋裹を見ると遠侍と式台の接合部分は共通の材で済むはずの小屋 束が二重に存在するなど、独立した遠侍の屋根に後から式台の屋根 を接続した様子が明らかで、式台を後から接続したとする指摘と符 合する。しかし、慶長度の様相を知る明確な資料を欠き、これ以上 の検討は困難である。

\section{3.二の丸御殿障壁画の料紙寸法による検璟}

\section{3-1 諸御殿の料紙寸法}

障壁画検討の一方法として、料紙寸法の分析を行うことが建築の 復原考察上も有効なことはすでに述べた通りである ${ }^{322 。 1 ~}$ の縦方向の寸法について、表面に見えている寸法と重ね合わせの寸 法（絹代といってもよい）を実測し、縦軸に表面に見えている寸 法、横軸に実寸法（表面に見えている寸法と重ね合わせの寸法の合 計）をとつてグラフを作成し検討した。白書院についてはすでに報 告した ${ }^{33}$ ので、ここでは大広間と黒書院のグラフを示すと図8・9の
如くなる。

白書院の場合は、 5 室とも共通して、建具グループと貼付グルー プに分かれ、さらに貼付グループは内法長押の上と下とに分かれた のであったが、他の御殿は次のような特性を示している。

まず、大広間・式台・遠侍は、貼付も建具も、内法長押の上も下 もすべて同じ寸法で、トコだけが大きいという共通する様相を見せ る。次に黒書院は、内法長押の上と下は差がなく、建具と貼付で寸 法が異なる。

このように、二の丸御殿の料紙寸法は、(a)大広間・式台・遠侍、 (b)黒書院、(c)白書院、この3つのグループに分けられる34。

\section{3-2 神紙寸法と担当奉行}

上に述べた料紙寸法のグループ分けは、すでに報告した通り ${ }^{36)}$ 、 大広間・式台・遠侍が五味金右衛門、黒書院が小野宗左衛門、白書 院が小堀政一という、寛永度造営の 3 人の造営奉行の担当の別 ${ }^{35)}$ と 一致している。

この事害が示唆するのは、料紙が奉行によって選択・採用された のではないかということである。その可能性は高いのだが、しかし、 例えば黒書院の場合、なぜ建具と貼付で料紙が異なっているのか、 奉行だけではうまく説明できない。貼付と建具の担当は、現在の用 語で言えば経師と建具職と、職種が異なることが多いから、黒書院

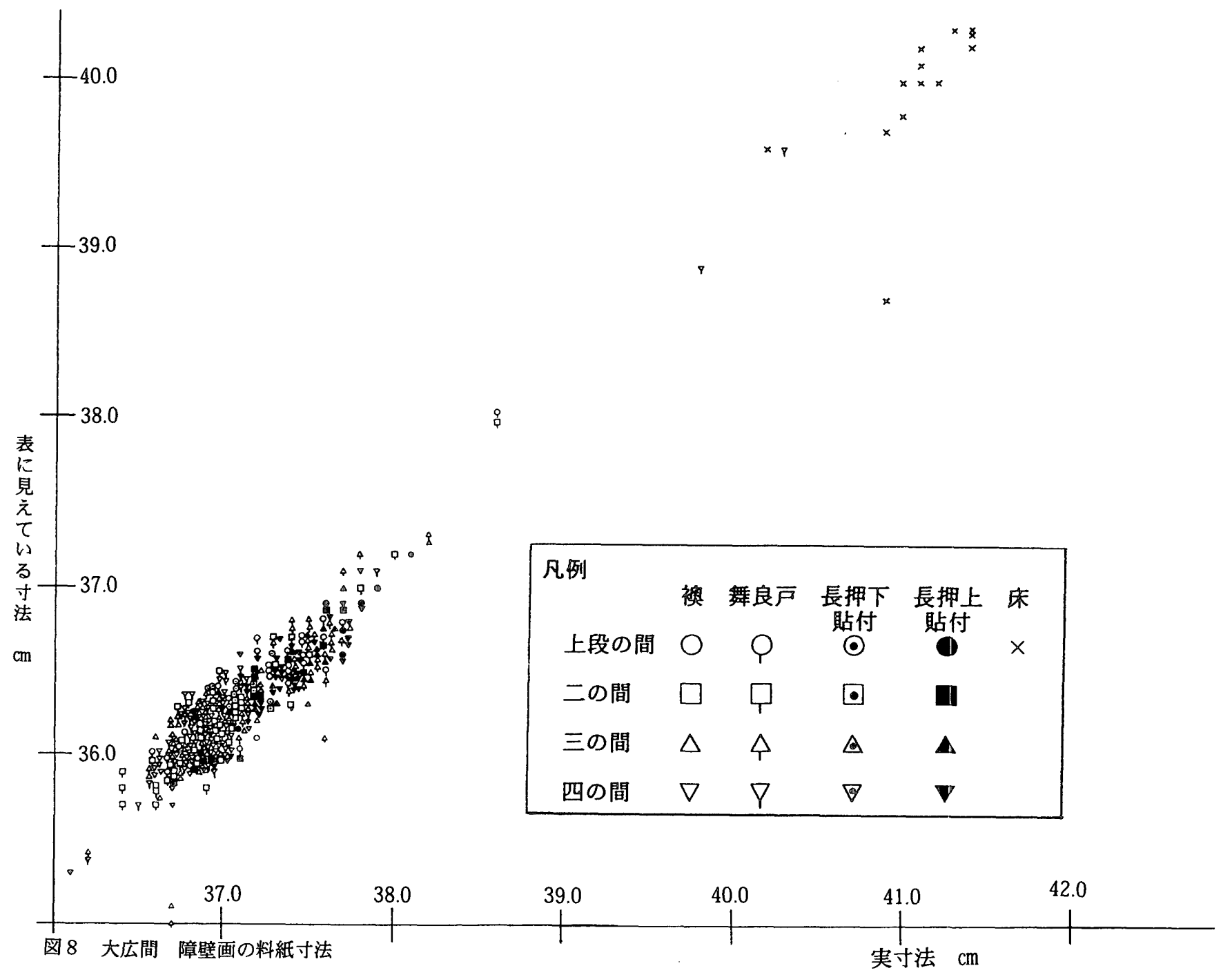


の場合は担当した職種によって料紙寸法の扱いが異なっていた可能 性を示唆する。また、白書院の場合、貼付のうち内法長押の上と下 では料紙が異なるから、担当の職種は同じでも工事の進行状況の違 いによって料紙の扱いが異なっていた可能性も考えておく必要があ る。

このように、誰が料紙を選択・採用したか、この点を料紙だけを もとに論ずるのは容易ではない。しかし、この 3 つのグループが料 紙の特性を異にしていることは確かであって、今後、筆者の問題な どの分析においては、この点をふまえた検討が必要である。

おわりに

二条城二の丸御殿のうち、大広間を中心に慶長度御殿の復原検討 を行い、また障壁画について料紙寸法の分析を行った。判明した諸 点を列記すれば、次の通りである。

(1)大広間の慶長度平面について、上・中・下段構成の主要な 3 室や 座敷飾が復原された。

(2)大広間の慶長度復原平面は、『匠明』殿屋集「当代広間ノ図」と 類似する。

(3)黒書院は、寛永殿造営では慶長度平面をあまり改変しなかった。

(4)式台・遠侍は、慶長度平面を復原するには資料が不足するが、い くつかの復原に関する知見が得られた。
(5)障壁画の料紙寸法は、白書院、黒書院、大広間・式台・遠侍の 3 つのグループに分けることができ、それは寛永度の造営奉行の別 と一致する。

なお、障壁画の検討については、美術史の大手前女子大学教授武 田恒夫・学習院大学教授千野香織両氏のご教示を得た。また、調査 に当たっては、元離宮二条城事務所の宇野幸次（当時）・高橋脩二

・坂井清の諸氏にお世話になった。記して感謝したい。

[墪]

1）澤島英太郎・吉永義信 『二條城』相模書房・1942年、「二条城の創建及 び沿革に関する考察」『重要文化財二条城修理工事報告書第三集』恩賜 元離宮二条城事務所・1958年、川上貢「二条城の規模と建築の变遷」 『元離宫二條城』小学館・1974年、平井聖・斉藤英俊「三条城二の丸微

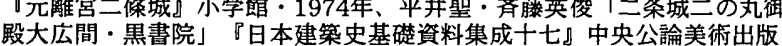
-1974年、西和夫「三条城の建築史一造営実体の探求」『名宝日本の 美術姫路城と二修城』小学館・1981年・改訂版1991年などがある。 修理工事については『重要文化財二条城修理工事報告書第 1 集〜第 5 集』元離宮二条城事務的・1955 76年、があり、障壁画については土居 次義「障壁画 三之丸御殿遠侍・白書院」前掲『元離宮二條城』、武田 恒夫「障壁画三之丸御殿大広間・式台・黒書院」前揭『元離宮二條 城』、山根有三「満院の障壁画」『全集日本の古寺第六巻』集英社・ 1985年、松木寛『御用絵師狩野派の血と力』講談社・1994年、などがあ

2) 西和夫・小沢朝江「二条城二の丸御殿白書院の復原研究一建築と障壁 画の総合的检討」 日本建築学会計画系論文報告集第489号・1996年11 月。

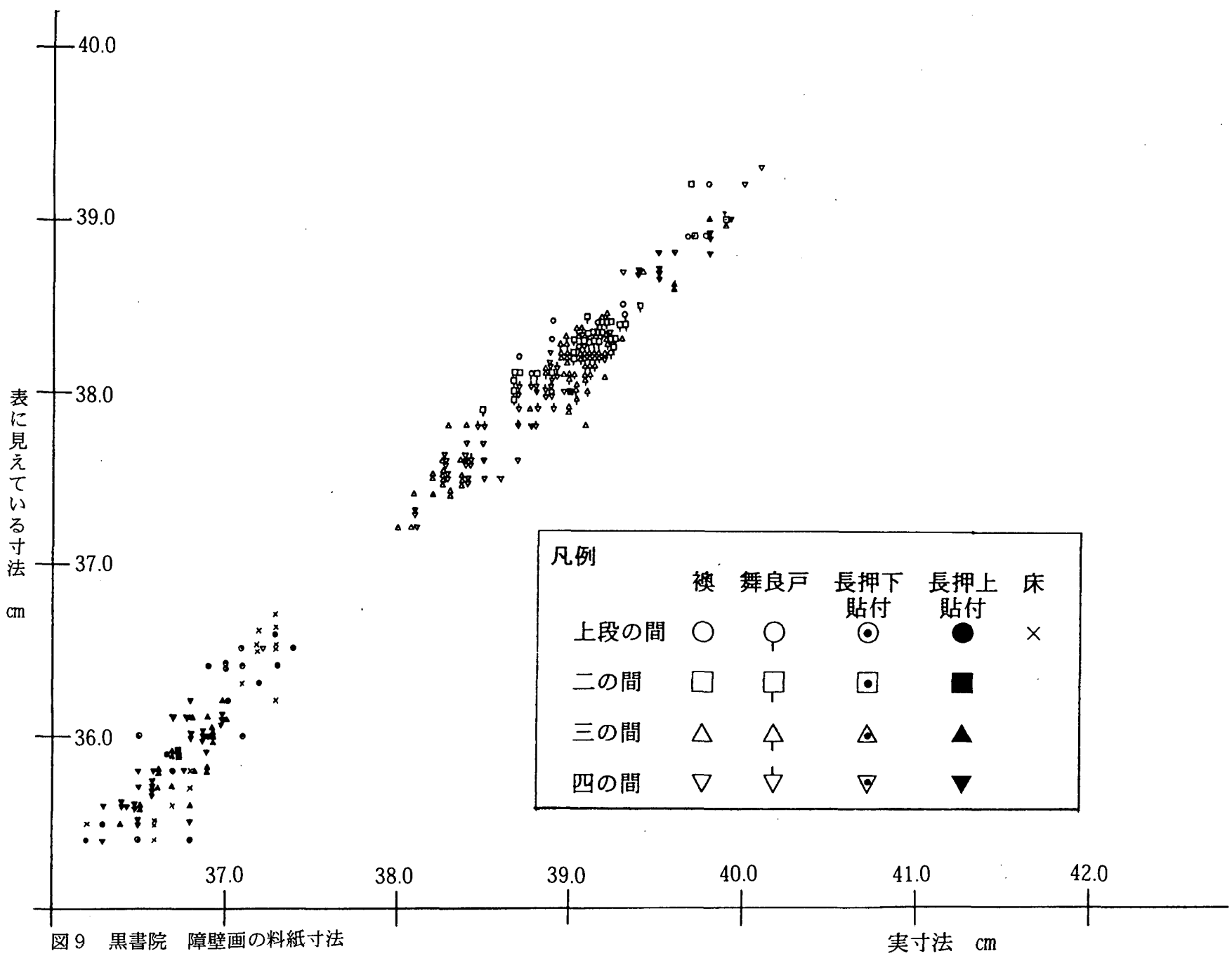


3）すでに次い論文で大広間の復原について報告したが、その後の検討の 結果、多くの新たな知見を得ることができた。また一部は先の報告と見 解が異なるところも生じているので、今回、既発表論文を前進させてこ こに報告することにした。西和夫「二条城二之丸御殿大広間の慶長度創 建時の平面について」日本建築学会大会学術講演梗概集・1980年、西和 夫・小沢朝江「二条城二の丸御殿の研究—建勧平面と障壁画の復原(上) (下) 国華第1068 1071 号・1993年3月・6月、西和夫・小沢朝江・天木 詠子「二条城二の丸御殿における建筑と障壁画の総合的検邻一白書院 · 大広間の鹿長度平面の復原を中心に」日本建築学会大会学術請演梗概集 -1993年9月、小沢朝江「家康の御殿・大広間の復原」『名城シリーズ 二条城』学研・1996年。

4) 註 3 の諸論文。

5）一部は註 3 の諸論文で触れたが、その後の知見を生かし、また新たに 根抱を示して説明する。

6）柱 $\mathrm{D} \sim \mathrm{F}$ の柱列には梁がなく、柱 $\mathrm{E}$ は独立して立っている。また、柱 Dと Fは南北方向の梁の下に位置するが、ほぞ等で架いでおらず、梁と の間に腺間がある状態である。

7）大広間の釣束は、頂部を 2 本の金具で梁から验っており、I の位圈に は、梁側面にこの金具を止めた当たりと鲀跡がある。

8) も方々ん座影飾 4 種が揃っていたとは限らないが、時代背景や家康の 御殿であることからみて、揃っていた可能性が高いことを認めてよかろ う。

9）完碓宮二条城事務所宇野幸次氏 (当時) のご協力により、トコ裹北面 の壁板 (舞良仕様になっている) をはずすなどして柱痕跡の調查を行つ た。

10)足法寺大方丈（京都府、寛永 7 年）などの例がある。

11)註 1 西和夫論文。

12)『二条御城御作亭御材木高払帳扣』（京都府立総合疼料館蔵）「二八丸 広問仕直シ」など。

13)現在の部材との比較、および同じ寛永度二条城造営の材木帳のうち材の 用途の記載のある『二条御城二ノ丸北之御殿御材木払帳扣』との比較に よる。

14)長さ 2 間の根太を真西方向に 1 間 4 ツ割で贺けたとして計算すると、相 太の本数は 7 本 $(4$ 間 $\times 2 / 3) \times 2$ 列で14本となる。また、ユ力板は、 東西 4 間（26尺）を 1 尺5 寸幅の板で張ると11.5枚必要で、これが南北 方向に 4 列あるため 11.5 枚 $\times 4$ 列 $=46$ 枚となる。

15)註14と同様。

16)材木㟪には「松、六間木、末口武尺五寸、武本」とあり、この寸法は、 現在大広間の柱 $N$ を通る南北柱列上に架かる大梁の寸法に合致する。
17)註13に同じ。

18)二条城䙾永度造営の造営奉行については、註 1 川上論文。

19)後に類似例として示す『匠明』殿屋集の「当代広間ノ図」の場合も、こ の位置に柱がある。

20)柱 J・Kには、現在のユカ高よりやや上に釘跡があり、工藤圭章氏はこ れを稳長度の上段框の痕跡であるとされた「金碧まばゆい将軍上洛の 館」(『不滅の建築11 三条城二の丸御殿』每日新䦥社、1989年)。しか し、これ以外に室内にはユカの高さを示す痕跡がなく、また柱 $\mathrm{A} ・ \mathrm{~B}$ ・ Cに残るユカ板の当たりの高さは現在の一の間と同じであって、慶長度 の上段の間のユカ高が現在の一の間の高さであったことを裹付ける。柱 $\mathrm{J}$. Kの鲀跡は、慶長度のユカの高さを直接示すものではないと考えら れる。

21)東京大学建築学科蔵。『匠明』鹿島研究所出版会・昭和46年。

22)「当代店間/図」に纥間什切位置に「フスマ障子「「杉障子」などの書 き必みがあるが、連続した 3 室のうち第 3 室とそれに連続する部屋との 境には書き込みがないことから、この位圆には建具がなかったと考えら れる。

23)大工工数の検討は、註 1 西論文。

24)例之ば、ユ力板之考爷られる杉四々料・長 7 尺・ 1 尺 5 寸 $\times 5$ 寸の材 は、大広間が524枚、黒書院が89枚ある。

25)註 2 に同じ。

26)現在、白書院と黒書院の廊下は西側に設けられているが、『二條御城御 指图』(中井家蔵) 等によれば、䙾永行幸時には東側に廊下があった。 27)『なごや御城御絵図』中井家藏。

28)この点については、註 1 平井・斉藤論文がすでに指摘している。

29) 『二条御城御作事御材木高払艮扣』(京都府立総合資料館蔵) 「二八 殿上ノ間作直シ二迎」など。

30)例えば、割木・2間木・8寸角の場合、「作直シ」と書かれた材が 7 本、「作直シ」と書かれていない材が120本ある。

31)註 1 平井・斉藤論文。

32)註 3 国華論文、および西和夫・小沢朝江ほか「園城寺谸学院客殿・光浄 院客殷の障壁面の料紙寸法による検討」 日本建筑学会関東支部研究報告

集、1994年 3 月。西和夫「名古屋城本丸御殿とその障壁画について」日 本建筑学会大会学術講演梗概集、1994年 9 月。

33)註 2 に同じ。

34)この点については、註 3 国華論文ですでに報告した。

35)註18に同じ。 